\title{
Sosialisasi Penggunaan Game Matematika Bagi Siswa Madrasah Ibtidaiyah Al Hidayah Makassar
}

\author{
Indrabayu $^{1}{ }^{*}$, Ingrid Nurtanio ${ }^{1}$, Christoforus Yohannes ${ }^{1}$, Zulkifli Tahir ${ }^{1}$, Ais Prayogi ${ }^{1}$, \\ Anugrayani Bustamin ${ }^{1}$, Riny Yustica Dewi ${ }^{1}$, Rizka Irianty ${ }^{1}$ \\ Departemen Teknik Informatika, Fakultas Teknik Universitas Hasanuddin ${ }^{1}$ \\ indrabayu@unhas.ac.id*
}

\begin{abstract}
Abstrak
Matematika merupakan mata pelajaran penting yang diajarkan di sekolah, sebab matematika melatih kemampuan menalar dan pola pikir para siswa. Namun, masih banyak siswa yang merasa kurang berminat pada mata pelajaran matematika. Hal ini berdampak pada kepada pencapaian belajar siswa yang kurang baik. Salah satu solusi untuk meningkatkan minat belajar siswa adalah dengan menggunakan alat bantu yang memanfaatkan teknologi. Pengabdian masyarakat yang dilakukan di Madrasah Ibtidaiyah Al Hidayah Makassar ini bertujuan untuk memberikan wawasan baru bagi siswa terkait metode dan materi pembelajaran digital dalam ruang lingkup sekolah juga untuk menumbuhkan motivasi belajar matematika yang sering dijadikan momok menakutkan bagi siswa. Pelaksanaan pengabdian pada masyarakat ini dibagi dalam 2 tahap, yaitu tahap sosialisasi metode pembelajaran dengan memanfaatkan teknologi, dalam hal ini smartphone android, dan tahap pelatihan penggunaan aplikasi edukasi Mathology. Pengabdian masyarakat ini merupakan ajang sosialisasi hasil-hasil penelitian terkait aplikasi yang dapat membantu proses pembelajaran dari Departemen Teknik Informatika, Fakultas Teknik, Universitas Hasanuddin.
\end{abstract}

Kata Kunci: Sosialisasi; Game; Matematika; Pembelajaran Digital; Aplikasi Android.

\begin{abstract}
Mathematics is an important subject taught in schools. Learning mathematics gives students' the ability to reason and develop their mindset. However, many students feel less interested in mathematics. This results in students' poor learning achievesment. One solution to increase student interest in learning is to use tools that utilize technology. The community service carried out at Madrasah Ibtidaiyah Al Hidayah Makassar aims to provide new insights for students regarding digital learning methods and materials at school. It also aims to foster motivation to learn mathematics, which is often seen as a fearful subject by students. The implementation of this community service is divided into 2 stages, which are the stage of socializing the technology-based learning methods, in this case using android smartphones, and the training stage on how to use the Mathology educational applications. This community service is also a venue for disseminating the research regarding the application ofinteractive learning media from Department of Informatics Engineering, Engineering Faculty, UNHAS.
\end{abstract}

Keywords: Socialization; Game; Mathematics; Digital Learning; Android Application.

\section{Pendahuluan}

Matematika salah satu mata pelajaran yang diajarkan di sekolah dasar mempunyai posisi yang sangat penting, sebab disamping dapat memberi bekal kemampuan berhitung, juga memiliki peranan besar dalam kehidupan sehari-hari yang dapat membentuk sikap, kecerdasan, dan kepribadian seorang anak. Namun, matematika seringkali menjadi mata pelajaran yang ditakuti oleh siswa, sehingga minat belajar matematika siswa kurang. Hal ini mengakibatkan kepada pencapaian belajar siswa yang kurang baik (Prayuga dan Abadi, 2019).

Minat belajar merupakan faktor yang sangat berpengaruh dalam kegiatan belajar mengajar. Dengan adanya minat belajar siswa dapat memberikan perhatian lebih dalam pembelajaran matematika. Rendahnya minat belajar di sekolah salah satunya dipengaruhi oleh metode 
pembelajaran yang diterapkan oleh guru secara konvensional. Oleh karena itu, berbagai pendekatan dilakukan untuk meningkatkan minat siswa untuk belajar. Salah satu pendekatan yang telah dilakukan peneliti terdahulu adalah dengan membangun game edukasi matematika yang berjudul "Mathology". Game ini ditargetkan untuk pembelajaran pada jenjang pendidikan kelas 4 Sekolah Dasar (SD) keatas dan dapat berjalan di smartphone android (Indrabayu, dkk., 2016). Game edukasi lainnya dibangun dalam bentuk game RPG (Role Playing Game) yang membimbing siswa untuk mempelajari tabel unsur periodic dalam mata pelajaran Ilmu Pengetahuan Alam (IPA) (Areni, dkk., 2019).

Salah satu solusi untuk meningkatkan minat belajar siswa adalah dengan menggunakan alat bantu yang memanfaatkan teknologi. Pelaksanaan pengabdian masyarakat ini ditargetkan untuk siswa Madrasah Ibtidaiyah Al Hidayah sebagai subjek dari proses kegiatan penggunaan aplikasi pada pembelajaran matematika yang merupakan komponen utama dalam menentukan hasil belajar. Hasil belajar siswa sangat ditentukan dari beberapa faktor, antara lain motivasi belajar dan keaktifan siswa dalam mengelolah dan menerima pembelajaran yang telah diberikan guru. Mata pelajaran matematika sudah diterapkan dalam Madrasah Ibtidaiyah Al Hidayah namun motivasi belajar siswa masih perlu ditingkatkan lagi dengan memperkenalkan metode pembelajaran baru dengan memanfaatkan teknologi. Selain di sekolah, kursus merupakan pilihan tepat bagi orang tua untuk memberikan pengetahuan matematika kepada anak-anaknya tetapi biaya yang harus dikeluarkan oleh orang tua tidaklah sedikit. Sehingga kemampuan matematika untuk siswa madrasah masih kurang.

Secara garis besar, permasalahan pokok yang dihadapi oleh guru, siswa dan orang tua siswa di Madrasah Ibtidaiyah Al Hidayah terhadap pengembangan pengetahuan matematika adalah metode yang diterapkan guru masih terbilang sederhana. Guru hanya memberikan contoh dan soal-soal hitungan untuk mata pelajaran matematika tanpa penggunaan media, seperti komputer atau smartphone sehingga motivasi belajar siswa terhadap mata pelajaran matematika masih terbilang jauh. Masalah lainnya adalah pemanfaatan smartphone siswa yang tidak efisien. Terdapat beberapa siswa Madrasah Ibtidaiyah Al Hidayah telah menggunakan smartphone, ketika pulang dari sekolah keseharian siswa lebih banyak menggunakan waktunya dengan smartphone namun tidak dimanfaatkan sebagai media pembelajaran untuk meningkatkan pengetahuan siswa tetapi hanya digunakan bermedia sosial dan game saja.

Pengembangan media pembelajaran yang dibuat diharapkan dapat memudahkan guru dan siswa serta meningkatkan minat siswa dalam belajar, mengingat dan memahami matematika dengan menggunakan media pembelajaran yang lebih interaktif.

\section{Dasar Teori}

Gambaran tentang kondisi pendidikan di Kota Makassar dipaparkan dalam dua kategori yaitu lingkungan internal dan lingkungan eksternal sebagai faktor strategis yang sangat mempengaruhi kinerja Pemerintah Kota Makassar dalam mewujudkan pencapaian visis yang telah ditetapkan. Lingkungan internal merupakan faktor lingkungan yang langsung berpengaruh pada kinerja organisasi yang umumnya dapat dikendalikan secara langsung, sedangkan lingkungan eksternal merupakan faktor lingkungan yang berpengaruh terhadap kinerja organisasi akan tetapi di luar kondisi organisasi Pemerintah Kota Makassar. Secara umum kondisi pendidikan dasar di Kota Makassar secara internal digambarkan dengan sejumlah fasilitas dan pencapaian melalui program yang telah dan sedang berjalan dengan tendensi dasar mengacu kepada data Angka Partisipasi 
Kasar (APK), Angka Partisipasi Murni (APM) dan Angka Partisipasi Sekolah pada jenjang pendidikan dasar (Haruna, 2009). Kota Makassar yang merupakan ibukota Provinsi Sulawesi Selatan juga memiliki banyak sekolah yang berlandaskan ilmu Agama Islam. Salah Yayasan pengembang Pendidikan di Kota Makassar yaitu Yayasan Al Hidayah. Yayasan ini mengembangkan sekolah untuk level Pendidikan Taman Kanak-Kanak sampai dengan Sekolah Menengah Atas (SMA). Sekolah dasar atau Madrasah Ibtidaiyah (MI) Al hidayah salah satu sekolah dasar yang dikembangkan oleh Yayasan ini. Jumlah guru pada sekolah ini yaitu 12 orang dan jumlah muridnya yaitu 135 orang. MI Al Hidayah mengadopsi kurikulum Kementerian Pendidikan dan Kebudayaan yang disertai dengan penguatan ilmu Agama Islam sebagai pelengkapnya. Gambar 1 menunjukkan lokasi peta geografis MI Al Hidayah Makassar.

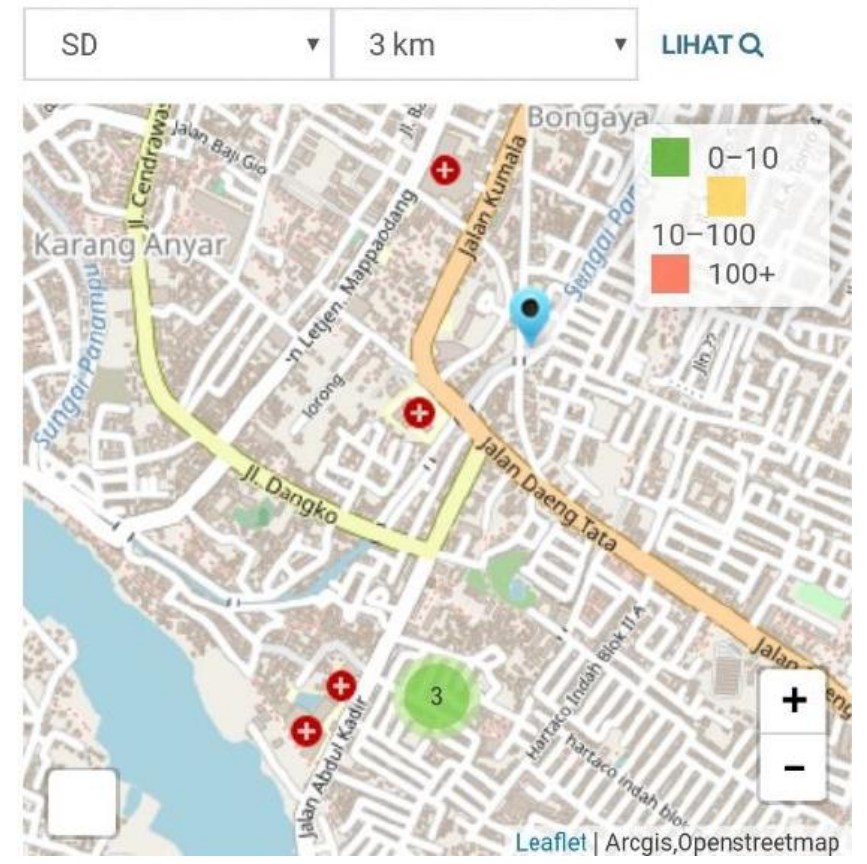

Gambar 1. Lokasi MI Al Hidayah Makassar

Pembelajaran digital secara luas merupakan bentuk proses belajar dengan pemanfaatan teknologi informasi baik menggunakan internet maupun yang tidak berbasis internet. Penggunaan portal semisal blog atau aplikasi pembelajaran interaktif menjadi salah satu contohnya. Namun, pembelajaran digital di sini lebih ditujukan pada usaha dalam membuat transformasi model pembelajaran sekolah maupun perguruan tinggi dalam representasi digital. Model pembelajaran digital dapat dibagi dalam 2 yaitu electronic based learning dan internet based (Munir, 2017). Model seperti ini telah banyak dikembangkan dan diaplikasi pada lembaga-lembaga pendidikan. Banyak guru yang telah menciptakan informasi terkait mata pelajarannya yang dikemas dalam bentuk blog maupun video yang kemudian dibagikan untuk dijadikan media pembelajaran digital. Portal pembelajaran pun telah disiapkan oleh pemerintah untuk dapat dimanfaatkan. Kedepan, semakin bertambahnya pemakai internet dan kesadaran akan penggunaan internet secara sehat, diprediksikan perkembangan pembelajaran digital melalui internet dalam pembelajaran akan semakin meningkat pesat. 
Dewasa ini, pemanfaatan teknologi dalam menunjang proses pembelajaran semakin berkembang seiring dengan perkembangan teknologi, salah satunya adalah aplikasi android. Bagi siswa Sekolah Dasar ataupun Madrasah Ibtidaiyah, belajar sambil bermain tentulah sangat menarik terlebih untuk mata pelajaran matematika. Sebagaimana diketahui bahwa matematika merupakan mata pelajaran yang dianggap sulit oleh siswa. Oleh karena itu, kami dari tim peneliti Departemen Teknik Informatika bekerjasama membuat aplikasi berbasis android yang dapat membantu proses pembelajaran khususnya matematika. Sebagaimana diketahui bahwa penggunaan smartphone sudah sampai ke daerah pelosok. Hasil penelitian tersebut yang akan diperkenalkan ke guru dan siswa Madrasah Ibtidaiyah Al Hidayah yang merupakan mitra kami pada kegiatan Pengabdian pada Masyarakat ini.

Aplikasi pembelajaran yang dibuat diharapkan dapat memberikan wawasan baru bagi guru dan siswa di Madrasah Ibtidaiyah Al Hidayah terkait metode dan materi pembelajaran, serta dapat meningkatkan motivasi belajar dan pemahaman siswa. Selain itu, pengabdian masyarakat ini juga sebagai ajang sosialisasi hasil-hasil penelitian pada Departemen Teknik Informatika.

Usaha yang dapat dilakukan untuk memecahkan masalah yang dihadapi oleh guru, siswa dan orang tua siswa di Madrasah Ibtidaiyah Al Hidayah adalah melalui penambahan metode belajar efektif yang dilakukan guru, peranan orang tua siswa dimunculkan, dan minat serta kebutuhan siswa terhadap peningkatan pembelajaran matematika seperti berikut ini :

1) Penambahan metode belajar efektif

Metode sederhana yang diterapkan guru masih membuat semangat belajar para pelajar masih tidak teratasi, sehingga guru perlu menambahkan metode belajar efektif dengan memanfaatkan smartphone atau teknologi terbaru, sehingga ketika pulang dari sekolah siswa dapat belajar matematika di rumah atau dimana pun siswa berada, pembelajarannya pun dibuat semenarik mungkin dalam bentuk game sehingga ada interaksi pelajar terhadap media pembelajarannya.

2) Peranan orang tua dimunculkan

Dengan keterbatasan pengetahuan orang tua terhadap pendidikan matematika sangat sulit untuk mendidik anaknya ketika telah pulang dari sekolah. Dengan adanya metode pembelajaran matematika dengan memanfaatkan smartphone akan memudahkan orang tua dalam peningkatan pengetahuan anaknya, khususnya untuk pelajaran matematika.

3) Minat dan kebutuhan pelajar terhadap peningkatan pemahaman matematika

Di kalangan siswa Madrasah Ibtidaiyah masih sulit untuk memunculkan minat siswa dalam belajar matematika dikarenakan metode pembelajaran yang diterapkan guru. Pemanfaatan teknologi dalam hal ini smartphone sebagai media pembelajaran diharapkan dapat meningkatkan minat siswa dalam belajar matematika.

\section{Metode Pelaksanaan}

Usaha-usaha yang dapat dilakukan untuk memecahkan masalah yang dihadapi oleh masyarakat di Madrasah Ibtidaiyah Al Hidayah adalah dengan melakukan sosialisasi dan pelatihan bagi guru dan siswa di sekolah tersebut dengan uraian sebagai berikut:

1) Melakukan sosialisasi tentang metode pembelajaran dengan memanfaatkan teknologi dalam hal ini smartphone khususnya untuk mata pelajaran Matematika. Memperkenalkan bagaimana belajar matematika dengan menyenangkan karena modul-modul pembelajaran dikemas dalam bentuk GAME di Smartphone. Pada tahapan ini juga dilakukan pembagian 
kuesioner untuk melihat ketertarikan model pembelajaran matematika yang selama ini siswa rasakan.

2) Melakukan pelatihan cara penggunaan Aplikasi Edukasi yang telah dibuat oleh tim pengabdian bagi guru, orang tua siswa dan siswa di Madrasah Ibtidaiyah Al Hidayah dengan membagi sesi sesuai modul yang telah disiapkan, yaitu modul untuk pelatihan aplikasi matematika. Setelah sesi pelatihan dilakukan, kuesioner post test terkait minat belajar siswa dengan metode pembejalaran dengan aplikasi matematika ini juga dibagikan.

\section{Hasil dan Diskusi}

Sosialisasi game edukasi Mathology yang sekaligus menjadi wujud kegiatan pengabdian masyarakat di Madrasah Ibtidaiyah Al Hidayah Kota Makassar telah dilaksanakan pada tanggal 2 September 2020. Kegiatan ini melibatkan guru dan siswa dalam kondisi terbatas sesuai dengan protocol Kesehatan mengingat waktu pelaksanaan dilakukan di masa pandemic Covid19. Jumlah peserta yang terlibat hanya 10 orang siswa didampingi oleh satu guru walaupun demikian tidak mengurangi antusias siswa dan guru untuk mengikuti jalannya kegiatan sosialisasi. Mathology merupakan salah satu karya penelitian yang dikembangkan dibawah naungan Departemen Teknik Informatika Universitas Hasanuddin. Game Edukasi ini merupakan media pembelajaran digital untuk Mata Pelajaran matematika pada level kelas 4-5 sekolah dasar. Adapun tampilan aplikasi dari game Mathology terlihat pada Gambar 1.
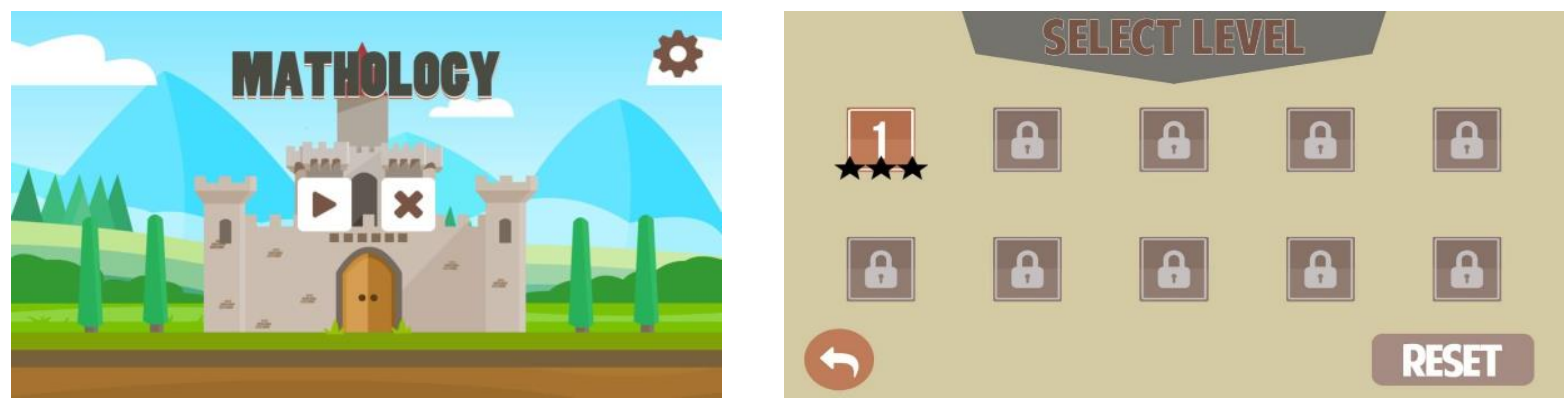

Gambar 1. Tampilan Game Edukasi

Evaluasi pelaksanaan kegiatan ini dilakukan dengan pemberian kuesioner pretest (sebelum sosialisasi) dan posttest (setelah sosialisasi) dengan masing-masing berjumlah 10. Kuesioner pretest ini diberikan untuk melihat sejauh mana ketertarikan minat belajar siswa MI Al Hidayah dengan metode pembelajaran yang diberikan oleh gurunya selama ini. Sedangkan untuk posttest, kuesioner ini berisi tingkat kepuasan dan minat belajar siswa setelah mengenal game edukasi Mathology.

Adapun alternatif jawaban pada saat pengisian kuesioner diwakili dengan skala likert seperti yang ditunjukkan pada Tabel 1 berikut:

Tabel 1. Alternatif jawaban kuesioner

\begin{tabular}{|c|}
\hline Alternatif Jawaban \\
\hline Sangat Setuju (SS) \\
\hline Setuju (S) \\
\hline Kurang Setuju (KS) \\
\hline Tidak Setuju (TS) \\
\hline
\end{tabular}




\section{Sangat Tidak Setuju (STS)}

Tabel 2-3 menunjukkan hasil pengisian kuesioner pretest dan posttest dari 10 siswa kelas 5 MI Al Hidayah.

Tabel 2. Hasil pengisian kuesioner pretest metode pembelajaran guru di MI Al Hidayah

\begin{tabular}{|c|l|c|c|c|c|c|}
\hline No & \multicolumn{1}{|c|}{ Pernyataan } & SS & S & KS & TS & STS \\
\hline 1 & $\begin{array}{l}\text { Saya senang belajar matematika dengan metode } \\
\text { pembelajaran dari Guru }\end{array}$ & 6 & 4 & 0 & 0 & 0 \\
\hline 2 & $\begin{array}{l}\text { Saya senang Ketika mendapat tugas Matematika dari } \\
\text { guru }\end{array}$ & 3 & 7 & 0 & 0 & 0 \\
\hline 3 & $\begin{array}{l}\text { Materi yang disajikan di papan tulis saya pahami } \\
\text { dengan mudah }\end{array}$ & 2 & 4 & 4 & 0 & 0 \\
\hline 4 & $\begin{array}{l}\text { Saya akan segera menyelesaikan tugas matematika } \\
\text { Ketika diberi tanpa disuruh }\end{array}$ & 1 & 3 & 4 & 2 & 0 \\
\hline 5 & $\begin{array}{l}\text { Saya merasa perlu untuk mengulang pelajaran } \\
\text { matematika dari catatan sekolah. }\end{array}$ & 2 & 8 & 0 & 0 & 0 \\
\hline 6 & Pelajaran matematika sangat sulit dipahami & 4 & 2 & 2 & 2 & 0 \\
\hline & TOTAL & $\mathbf{1 8}$ & $\mathbf{2 8}$ & $\mathbf{1 0}$ & $\mathbf{4}$ & $\mathbf{0}$ \\
\hline
\end{tabular}

Tabel 3. Hasil pengisian kuesioner posttest sosialisasi Game Edukasi Mathology

\begin{tabular}{|c|l|c|c|c|c|c|}
\hline No & \multicolumn{1}{|c|}{ Pernyataan } & SS & S & KS & TS & STS \\
\hline 1 & $\begin{array}{l}\text { Saya senang belajar matematika dengan metode } \\
\text { pembelajaran dari Guru dan dikemas dalam bentuk } \\
\text { Game }\end{array}$ & 5 & 5 & 0 & 0 & 0 \\
\hline 2 & $\begin{array}{l}\text { Saya senang Ketika mendapat tugas Matematika jika } \\
\text { disimulasikan dengan Game Mathology }\end{array}$ & 3 & 6 & 1 & 0 & 0 \\
\hline 3 & $\begin{array}{l}\text { Saya akan segera menyelesaikan tugas matematika } \\
\text { tanpa disuruh jika menggunakan Mathology }\end{array}$ & 5 & 1 & 3 & 1 & 0 \\
\hline 4 & $\begin{array}{l}\text { Pelajaran matematika jadi menarik jika dibuat dalam } \\
\text { bentuk game }\end{array}$ & 5 & 4 & 1 & 0 & 0 \\
\hline 5 & $\begin{array}{l}\text { Saya lebih senang belajar jika menggunakan media } \\
\text { (alat peraga, laptop dan HP) }\end{array}$ & 4 & 2 & 2 & 2 & 0 \\
\hline 6 & Game yang disajikan menarik dan bermanfaat & 5 & 4 & 1 & 0 & 0 \\
\hline TOTAL & $\mathbf{2 7}$ & $\mathbf{2 2}$ & $\mathbf{8}$ & $\mathbf{3}$ & $\mathbf{0}$ \\
\hline
\end{tabular}


Tabel 2 memperlihatkan respon siswa terkait model pembelajaran yang selama ini mereka lakukan dan terima dari guru. Hasil kuesioner menunjukkan beberapa siswa senang dengan pelajaran matematika namun proses pemahaman materi masih cukup sulit bagi siswa. Setelah mengikuti sosialisasi, antusias siswa terlihat dari hasil kueisoner yang mereka isi pada Tabel 3 . Sebagian besar siswa telihat antusias dan menunjukkan respon baik dengan sosialisasi game edukasi Mathology. Pelajaran matematika yang selama ini mereka dapatkan masih sebatas penjelasan dan tugas dari guru. Namun ketika dikombinasikan dengan penggunaan game edukasi matematika siswa menunjukkan pemahaman yang cepat dan membuat mereka lebih tertarik dengan pelajaran matematika.

Dokumentasi kegiatan sosialisasi dalam rangka program pengabdian masyarakat dapat dilihat pada Gambar 2 berikut ini.
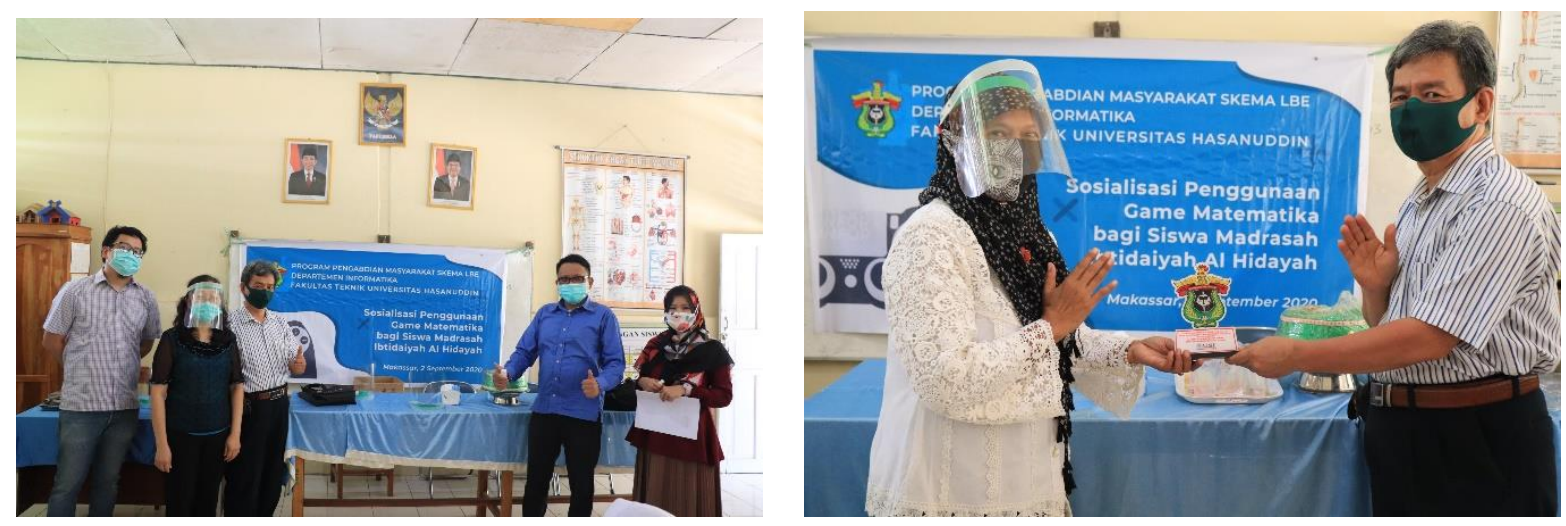

Gambar 2. Dokumentasi kegiatan pengabdian

\section{Kesimpulan}

Kegiatan pengabdian masyarakat Fakultas Teknik dari Departemen Teknik Informatika telah dilakukan. Bentuk kegiatan yang dilaksanakan yaitu sosialisasi pengenalan game edukasi untuk mata pelajaran Matematika yang kami beri nama dengan Mathology. Siswa dan guru Madrasah Ibtidaiyah Al Hidayah terlihat antusias dalam mengikuti sosialisasi ini. Pelajaran matematika yang selama ini mereka dapatkan masih sebatas penjelasan dan tugas dari guru. Namun ketika dikombinasikan dengan penggunaan game edukasi matematika siswa menunjukkan pemahaman yang cepat dan membuat mereka lebih tertarik dengan pelajaran matematika. Ini terlihat dari hasil kuisioner, dimana terjadi pergeseran nilai dari assessment ke arah semakin baik.

\section{Ucapan Terima Kasih}

Penulis mengucapkan terima kasih kepada mitra Madrasah Ibtidaiyah Al Hidayah, Kota Makassar atas kerjasamanya dalam pelaksanaan kegiatan pengabdian ini. Selain itu, penulis juga mengucapkan terima kasih kepada Fakultas Teknik Universitas Hasanuddin yang telah memberikan dana dalam bentuk hibah pengabdian masyarakat untuk tahun 2020 kepada kami selaku tim dari Departemen Teknik Informatika Unhas. 


\section{Daftar Pustaka}

Areni, I.S., Indrabayu, Muslimin, Z., Palantei, E., Prayogi, A. dan Bustamin, A., (2019). Pengenalan Pembelajaran Interaktif Berbasis Game di SDN14 Bonto-Bonto Kabupaten Pangkep, Jurnal Panrita Abdi, 3(2): 177-183.

Geoportal Makassar, (n.d.). Rencana Pembangunan Jangka Menengah Daerah Kota Makassar Tahun 2014-2019. Terdapat pada laman http://geoportalmakassar.info/downloadBab\%20II\%20GAMBARAN\%20UMUM\%20KONDISI\%20DAERAH.pdf.html. Diakses pada tanggal 19 September 2020.

Indrabayu, Mukarramah, Prayogi, A., Fajrin, A.R. dan Wahid, A., (2016). Game Edukatif "Mathology" Berbasis Android, Jurnal IBE.

Kementerian Pendidikan dan Kebudayaan, (2013). Kurikulum 2013 Kompetensi Dasar. Terdapat pada laman https://www.academia.edu/6441738/Kompetensi_Inti_dan_Kompetensi_Dasar_Kurikulum_2 013_SMP_dan_MTs. Diakses pada tanggal 19 September 2020.

Munir, (2017). Pembelajaran Digital. Terdapat pada laman http://file.upi.edu/Direktori/FPMIPA/PRODI._ILMU_KOMPUTER/196603252001121MUNIR/BUKU/Pembelajaran\%20Digital.pdf. Diakses pada tanggal 19 September 2020.

Prayuga, Y. dan Abadi, A.P., (2020). Minat Belajar SiswaDalamPembelajaran matematika. Prosiding Sesiomadika, 20(1d): 1052-1058. 